\title{
Scientific correspondence in the archive of the General Directorate of Agriculture under the Ministry of Agriculture Industry and Commerce
}

\author{
Nella Eramo \\ Archivio Centrale dello Stato, Roma, Italy
}

\begin{abstract}
The archive, which testifies the activity of the offices dedicated to geological studies and to the collection of meteorological investigations from 1870 to 1895, contains important files of scientific correspondence. The latter includes letters from scientists, members of the councils, committees and research commissions established under the Ministry of Agriculture Industry and Commerce, as well as correspondence of technicians who were charged with particular duties by the administration, like Nicola Maraglia, general director for Agriculture, and Felice Giordano, director of the Service of the Mines. They are rich in news, opinions, observations and reports portraying scientific events and personalities of the time. As an example, some documents concerning the following topics are illustrated: the origins of the Central Office of Meteorology and the role of Giovanni Cantoni; the establishment of a service for the systematic collection of data about seismic phenomena, by Michele Stefano De Rossi; the activity of the Geodynamic Commission; the project by Giulio Grablowitz for the construction of the observatory of Ischia.
\end{abstract}

Key words geological map of Italy - international geological congresses - central office of meteorology - geodynamic service - seismological observatory of Ischia

\section{Scientific competencies of the MAIC and correspondence in the earth sciences pre- served in the archive}

Decree no. 4192, 5th July 1860, which established the competencies of the Ministry of Agriculture Industry and Commerce (MAIC), also

Mailing address: Dr. Nella Eramo, Archivio Centrale dello Stato, Piazzale degli Archivi 27, 00144 Roma, Italy; e.mail: neramo@archivi.beniculturali.it introduced an activity of experimentation and study aimed at perfecting methods and techniques in the various economic sectors and at increasing agricultural and industrial education (Caracciolo, 1960). According to the prevalent opinion at the time, a good administration, «without taking the place of private forces», was supposed to «illuminate» and uphold the productive world by assuming the burden of informing and diffusing technical and scientific knowledge (De Cesare, 1868). A division for general statistics is known to have been created under the MAIC since 1861. The meteorological, geological and seismic services for the new unitary State, instead, were initiated between the seventies and the eighties under the Department for Agriculture, which became General Directorate in 1883 (Eramo, 1995); hydrographical surveys pertaining to the whole national territory were al- 
so instituted (Eramo, 1996). Therefore, as well as files concerning mainly agricultural subjects such as «agrarian stations and laboratories», «practical and specialised schools of agriculture», «vegetal pathology», «zoology and veterinary», etc., the General Directorate archive containes documents related to the activity of offices involved in hydraulics, land reclamation and irrigation studies, meteorology, mineralogy, geology, volcanology and geodynamics. The chronological range of the fonds extends from 1860 to the end of the century; although, more ancient records are present, produced by the different pre-unitary administrations.

The correspondence available in the archive shows the role of scientists, professors and technicians during the establishment of the Ministry's scientific services, as well as during their later development, when directly responsible for the administration and when members of councils, committees and research commissions. Such documents are not often known because they have remained hidden inside ponderous files of an essentially administrative nature. They are important, however, for their potential to enlighten the reasons, conditioning and motivations for the choices made and the directions followed. On one hand, the letters of scientists addressed to the minister, the directors, the inspectors and the presidents of committees tell us about a whole activity aimed at informing, convincing, educating and supporting the administration's work; on the other hand they show the willingness and the awareness of some of those in charge of the services towards the occurring needs. Still to be better analysed, but absolutely fundamental, is the role of Nicola Miraglia, director of agriculture for over thirty years (from the end of the sixties to the nineties of the 19th century), who ensured the continuity of the Ministry's policy and was able to effectively mediate between the proposals of scientists and the ministerial decisions, often conditioned by budget constraints.

\section{Geology}

Classified as «Geology» are all the files contained in more than fifty folders and related to: general affairs, congresses held in Italy and abroad, exhibitions, the geological map, geological offices, personnel, geological and mining education. The documents include: the minutes from the Advisory Committee charged to establish the methods and rules for the geological map; the correspondence with the Geological Committee, which was entrusted with the high scientific direction of the surveys; all work progress reports from the geological engineers; etc. They can offer important information about the origins of the service and its actual running till 1895 .

As an example, I quote a document from the beginning of the unitary State, a note by Felice Giordano, chief inspector of the Corps of Mines, addressed to the minister of Agriculture, Tommaso Corsi, on 19th October 1860, about the «Geological map of the Country» $\left(^{1}\right)$. Giordano, mining engineer in the Ministry of Agriculture and Commerce from the early fifties, later in the Ministry of Public Works of the Kingdom of Sardinia, was nominated chief of the Inspectorate of the Mines. Afterwards, from December 1866, he became a member of the Geological Committee, as well as Director of the Service of the Mines and of the surveying activities for the geological map until 1892, the year of his death $\left(^{2}\right)$.

This report synthesises the events that led, with the royal decree of 28th July 1861, to the establishment of the Advisory Committee. It proves Giordano's belief, already mature in 1860 , that the new State required a scientific instrument fundamental also for the development of productive activities. Aware that «there are issues which, although implying a long term solution, already require a direction to define the most adequate elements for the purpose» $\left({ }^{3}\right)$, he underlines the importance, «for a progressing State» $\left({ }^{4}\right)$, of a process which, at that time, other nations in Europe and America had already accomplished or started: «Marking in different colours, on each region's map, the masses of the different grounds constituting its framework or subsoil, sorted by age of formation, is of a high scientific interest as it refers to the chronology of their subsequent formation. It is, in fact, of a highly practical value because the genesis of lands and their underground structures are essential elements for all industries, 
which directly or indirectly depend on the mineral realm. Among these, stands the agricultural industry for which it is important to know the layout and the extension of lands of different formation and nature [...]. It is also pertinent to all the operations related to sewers, irrigation canals, water sources and, more generally, the safe accomplishment of public works» $\left(^{5}\right)$.

News and references to the work and the positions of scientists from other countries can be found in the correspondence of engineers and professors, members either of the International Committee for the Geological Map of Europe or of the International Commission for the Unification of the Geological Nomenclature; as well as in the reports written for the minister by the participants in international conferences.

Worthy of note, for example, is the file on the International Conference of Geology in London $\left({ }^{6}\right)$, held from 17th to 22nd September 1888, which includes, among other things, the reports sent by Giordano and Giovanni Capelli$\mathrm{ni}$, director of the Reale Istituto geologico e paleontologico of the University of Bologna and president of the International Commission for the Unification of the Geological Nomenclature. On a note written on 21st November 1888, the minister Bernardino Grimaldi expressed doubt about the benefit of the Italian participation in the geological conferences, as in London no significant decision had been taken about the items on the agenda, which concerned the «classification of the Cambrian and the Silurian and the limits of the Tertiary and Quaternary». In his reply, on 27th November, Capellini recalled how, in the Conference of Manchester of 1887, the American geologists had proposed, to their English speaking colleagues, to create an association permanently based in London, aimed at dealing with all the issues related to geological nomenclature. Their intention was clearly to bring about the cancellation of the IV International Conference, due in London the following year. Capellini explains: «If I had not taken part in the discussion in Manchester, where such a proposal had to be evaluated, it would have probably been accepted, with great disadvantage to the geological studies in general and with sacrifice of our national self-respect in particular. The importance of the Internation- al Geological Conference became clear during the second session in Bologna in 1885, and as it is now widely acknowledged, it's our duty to stand our ground and fight» $\left(^{7}\right)$.

Another file, named «International Commission for the Unification of Geological Nomenclature» $\left({ }^{8}\right)$, contains a letter written on 23rd September 1887, where Capellini reports even more clearly what happened during the meeting in 1887. In Manchester he had managed to foil the attempt to institute a great association of Great Britain and all the depending colonies, in fact of all the English-speaking countries, including the United States of America, so that anything concerning the geological classification and nomenclature would be decided by this association rather than by the International Conference. The aim was to force all the remaining nations to accept the conclusions and the rules agreed in that association. Under the pretext that geologists of the other European nations could not reach an agreement, while it would be extremely simple for English speakers to do, without any apparent hostility, a deadly blow would have occurred for the International Conference, supposed to meet in London the following year.

\section{Meteorology}

The archive also holds numerous and copious files on meteorology, in particular related to the Central Office of Meteorology, from its institution in 1876 until near the end of the century.

It is undoubtedly worth carefully going through the abundant and regular correspondence between the director of Agriculture and Pietro Tacchini, director of the Central Office of Meteorology between 1879 and 1896, the last documented year in the archive. Worthy of note are also: the reports on the beginning of a systematic series of studies in the field of forestale meteorology, and, in particular, on the surveys conducted by Tacchini and Elia Millosevich in the woods of Vallombrosa and Camaldoli in $1881\left(^{9}\right)$; the correspondence between Tacchini and Angelo Celli about the installation of a network for the parallel measurement of nosographic and meteorological data, aimed at bet- 
ter identifying the connections between climatic-environmental conditions and malaria $\left({ }^{10}\right)$.

As other contributions in the conference are dedicated to Pietro Tacchini and to the period of his directorship of the Central Office, I would rather consider in more detail some files of the years 1873-74, when the Meteorological Office was taking its first steps and the surveys and measurements were still under the Division of Statistics, directed by Luigi Bodio. The technical direction of the service was then entrusted to the physician Giovanni Cantoni, who worked to rationalise and standardise the meteorological stations. The correspondence from that period shows a restless activity orientated to create a national central service. In a report for the Ministry on 30th December $1874\left({ }^{11}\right)$, Cantoni refers to the annual activity of the Meteorological Office. Based on what had been agreed in the International Conference of Vienna in 1873, about the need to introduce shared protocols for the measurement and the publication of data from the different european countries, a decadal bulletin was launched, where «in as many as twenty stations, spread on the surface of the peninsula, the parameters of the main meteorological events are compared; thus, even with a quick glance, it is possible to examine the general trend of the great perturbations and the daily variations that occurred all over Italy; then they can be easily compared to the ones registered in other regions of Europe» $\left({ }^{12}\right)$. Cantoni also declares that, compared to the previous year, thirteen more stations, out of a total of eighty, regularly send their meteorological notes to the Office.

He points out to Luigi Bodio that, within the MAIC, the Hydrographical Commission is collecting the measurements from pluviometrical stations installed in the major rivers' basins, so he proposes that the different offices systematically share their data. He also highlights how, in the same Ministry, an increasing number of agricultural stations are provided with rain and meteorological measurements, which could be published on the monthly bulletin with an increased benefit for both agriculture and meteorology. In the same way, all the data telegraphed by the harbour offices to the Ministry of the Navy should be shared as well. Using Cantoni's own words, he constantly underlines the necessity «to unify and revitalise the meteorological services, which lie unorganised and wasted under several ministries, by creating one central meteorological institute based on the Dutch, Danish and Swedish models; it should aim at coordinating the data measured by the numerous meteorological, maritime and hydrometrical stations present in our country» $\left({ }^{13}\right)$.

\section{Geodynamics}

The Central Office of Meteorology, instituted by the royal decree 26th November 1876 and directed by Tacchini from 1879, later acquired also the directorship of the geodynamic service $\left({ }^{14}\right)$.

Some documents on this service's events have been located. In particular, they concern: the role of the Observatory and Central Geodynamic Archive, founded in 1882 under the Royal Geological Committee and directed by Michele Stefano De Rossi, from the beginning to its drastic reduction, due to the unification of the geodynamic service and the Central Office of Meteorology in 1887; the work by the Royal Geodynamic Commission, established by the royal decree 20th December 1883; the design of the Observatory of Casamicciola.

The first steps of the service, based in Via Santa Susanna, are reported by De Rossi himself in a letter $\left({ }^{15}\right)$, whose subject was «Attribuzioni dell'Archivio Geodinamico», addressed to the general director Miraglia on 12th June 1888: «First of all I think I should remind the Ministry that in 1882 I was asked, directly by the minister, to move the geodynamic archive, that I created, under the Royal Geological Committee, in order to enhance it and to make it the centre of a geodynamic service, as well as the well known publication of the Italian Volcanism Bulletin. [...] I also recall how, in order to propose the final configuration for the new scientific service, the Royal Geodynamic Commission, later established, recognised the personal property of such an archive and of the associated geodynamic library, asking the Ministry to purchase them; such a proposal only involved the part preceding the year 1883 , when the collection of news and docu- 
ments started to depend on the small office whose direction was given to me by the Ministry» $\left({ }^{16}\right)$. The correspondence between the mentioned Central Archive, directed by De Rossi, and the prefects of the Kingdom is available. On 20th April 1883 a circular was sent to the prefects to ask for the systematic transmission of any news related to seismic events occurring in the various provinces, «[...] even those events whose low intensity wouldn't normally attract interest beyond the boundaries of the city or the place where they occurred» $\left({ }^{17}\right)$. The prefects immediately started to communicate important information to the office and proposed the installation of new measurement stations (27 new stations during 1883); they also signalled people and institutes that would organise direct and scientifically rigorous surveys for free, providing they were given the right means. That is what De Rossi states in his letter to Miraglia on 30th December $1883\left({ }^{18}\right)$, adding that the new stations, together with the other 39 major ones, would produce a very effective network of geodynamic analysis.

In the note De Rossi wrote on 16th December 1883 for Giordano, director of the geological service, he highlighted the necessity for the Observatory of Rome and for the other provincial ones to be provided with appropriate equipment. A detailed report, attached to the note, describes the first steps taken to institute the new service. It reads: "Among the other requirements of the geodynamic service, there is a need for mobile as well as fixed observatories. «Mobile observatories» are a set of portable instruments that can be used either for scientific excursions or to create temporary measuring stations, ready to be installed in case of sudden seismic activities. Such a need has been partially fulfilled, despite the lack of means, thanks to the availability of a limited number of instruments; during this year, mobile instruments have been working in Cascia in Palazzuolo, in Albano, in Serrara Fontana and in Ischia. While considering the geodynamic service's work, it is fundamental to mention the network of measuring stations, supplied with some seismographs, installed on the slopes of Etna; a central observatory has also been established in Catania, promoted by the director of the Meteoro- logical Office, Tacchini. Tacchini also provided the most valuable observatories with some seismoscopic detectors, for the analysis of more intense earthquakes» $\left({ }^{19}\right)$.

During the debate in Parliament on a law to define the institutional aid for the people affected by the earthquake of Ischia, on which occasion the Ministry of Agriculture was involved for the installation of a geodynamic observatory on the island, De Rossi wrote a letter (3th February 1884) $\left({ }^{20}\right)$ to the minister Domenico Berti, «[...] in order to make the use of some essential terminology clearer» $\left({ }^{21}\right)$. His purpose was to avoid confusion and to clarify the main objective of seismic studies and observations; he explained: «The study of the internal activity of the earth, that we call Geodynamics, is now made of continuous observations and based on special instruments, because this has been proved to be the only method to investigate its rules and to discover its causes. Even though the forecast of dangerous phenomena is not the direct purpose of this study, it could represent its final result; for this reason it is worth conducting such observations in all those places where seismic activity is most intense» $\left.{ }^{22}\right)$. He added that science cannot be expected to foresee the place and time of an earthquake or of an eruption, however «the experimental method based on scientifically regular observations, conducted in appropriate observatories, has proved the existence of precursory phenomena. When the course of such phenomena will be better understood, even the scientific prediction of the greatest phenomena will be possible» $\left({ }^{23}\right)$. So, regarding the observatory of Ischia, «it must not be used to inform the public daily about the dynamic configuration of the earth, but it will record all the different phenomena detected on the island. When an abnormal accumulation of these phenomena will occur, as happened before the earthquake of Ischia on 28th July, it will be possible to warn the population about the expectation of a similarly extraordinary event» $\left({ }^{24}\right)$.

It is also interesting to examine what appears from the documents concerning the Geodynamic Commission, which had the task to propose the final configuration of the geodynamic service. The Commission members, be- 
sides De Rossi, Tacchini and Giordano, were: Luigi Palmieri, director of the Vesuvian Observatory; Cerasio Silvestri, director of the Geodynamic Observatory of Catania; Galileo Ferraris, director of the Laboratory of Physics of the Industrial Museum of Torino; Francesco Denza, director of the Meteorological Observatory of Moncalieri; Giovanni Cantoni, member of the Council of Meteorology; Torquato Taramelli, director of the Museum of Mineralogy and Geology of the University of Pavia; Giulio Grablowitz, director of the Geodynamic Observatory of Casamicciola.

The correspondence between the President of the Commission, Pietro Blaserna (at that time, director of the Department of Physics in the University of Rome) and the General Directorate of Agriculture is particularly relevant, as it contains information and comments on the main subjects discussed in the Commission meetings. For example, in his letter dated 17th June $1886\left({ }^{25}\right)$, Blaserna writes: «The Commission considers neither useful nor appropriate to suggest to the government the establishment of a central geodynamic office. Since an extended network of meteorological stations already exists, and because there are many analogies between the meteorological and the geodynamic service, they could be joined in a single central office, under the competent guide of Tacchini» $\left.{ }^{26}\right)$.

The Geodynamic Commission also debated about the most suitable instruments and methods for the investigations. The contribution of the Commission members on this subject is highly criticised by Blaserna, who describes the reports by Palmieri and Silvestri as insufficient and consideres De Rossi's superficial description of the available instruments as a sign that he is underestimating the matter. Blaserna also adds: «Unfortunately we must admit that we have been overtaken by other countries and, if we had continued following our old ways, Italy wouldn't have been able to conduct strictly scientific studies on ground movements» $\left({ }^{27}\right)$. Commenting on the report by Grablowitz about the scientific instruments, whose publication he highly recommends $\left({ }^{28}\right)$, Blaserna refers to the Commission's decision about it: «The Commission holds that the future of seismic studies in Italy is based on the availability of recording instruments able to register the three components of ground movement. For this reason, the Commission suggests that the main observatories collect all the instruments listed in the report, in order to test and select them» $\left({ }^{29}\right)$.

The archive of the General Directorate of Agriculture also preserves important documentation on the history of the Observatory of Casamicciola. Several files concern the building of the observatory, in particular: the initial inspections performed by De Rossi, Tacchini, and Grablowitz; the preliminary design by Grablowitz (December 1884); the comments by Grablowitz about the feasible project drafted by the Ufficio speciale del Genio Civile. Worthy of note, as an example, are two reports by Grablowitz $\left({ }^{30}\right)$ : the first one, written on 18th December 1884 and addressed to the president of the Geodynamic Commission, is about the place and position of the observatory, the subsoil steadiness and the stability of the building, which are very important factors for the installation of the seismic instruments; the second one, sent to the Ministry of Agriculture Industry and Commerce on 28th September 1886 (when Grablowitz was the director of the observatory), illustrates the basic characteristics of the construction, like the optimum surface area, the perfectly square shape, and the dimensions of the central pillar.

\section{Notes}

( $\left.{ }^{1}\right)$ Archivio Centrale dello Stato (ACS), Ministero di Agricoltura Industria e Commercio (MAIC), Direzione generale dell'agricoltura (DGA), Versamento V, b. 951, fasc. 4193 «86/1. Carta geologica. Direzione scientifica. Giunta consultiva per la formazione della carta geologica», 1860-1865.

( $\left.{ }^{2}\right)$ ACS, MAIC, DGA, Versamento IV, b. 770, fasc. 4365 «84/1. Giordano comm.re Felice», 1852-1892.

$\left({ }^{3}\right)$ «Esistono questioni le quali, benché di lunga soluzione, esigono tuttavia sin d'ora una direzione che ne predisponga gli elementi allo scopo migliori». 
$\left(^{4}\right)$ «er uno Stato progrediente».

$\left(^{5}\right)$ «Il segnare sulla mappa delle diverse regioni con colori diversi le masse dei terreni che ne costituiscono l'ossatura o sottosuolo, distinte per l'età della loro formazione, è d'interesse scientifico in quanto si riferisce alla cronologia della successiva loro formazione, ed è però nel fatto di somma utilità pratica, stante che il modo della genesi dei terreni, la loro disposizione sotterranea sono gli essenziali elementi di tutte le industrie che dipendono in modo diretto e indiretto dal regno minerale. Fra queste primeggia l'agricola, per la quale è importante conoscere la disposizione ed estensione delle zone dei terreni di varia formazione e natura [...]. Ne dipendono anche tutte le operazioni, oggidì capitali, della fognatura, del tracciamento dei canali irrigatori, dell'allacciatura delle sorgenti, e in generale tutto il ramo dell'idrografia sotterranea».

$\left({ }^{6}\right)$ ACS, MAIC, DGA, Versamento V, b. 950, fasc. 4189 «85/1. Congresso geologico internazionale a Londra», 1888-1889.

${ }^{(7)}$ «Se io non avessi preso parte alla discussione a Manchester ove si doveva deliberare su quella proposta, essa sarebbe forse stata accolta favorevolmente con grande svantaggio degli studi geologici in generale e con sacrifizio del nostro amor proprio nazionale in particolare. L'importanza del Congresso geologico internazionale emerse nella seconda sessione in Bologna nel 1885 e, poiché oggi ciò è ammesso da tutti, a noi incombe l'obbligo di restare sulla breccia e lottare».

$\left.{ }^{8}\right)$ ACS, MAIC, DGA, Versamento V, b. 950, fasc. 4185, anni 1886-1888.

$\left({ }^{9}\right)$ ACS, MAIC, DGA, Versamento IV, b. 633, fasc. $3670 \ll 32 / 8$. Meteorologia forestale. Camaldoli», 1873-1886.

$\left({ }^{10}\right)$ ACS, MAIC, DGA, Versamento V, b. 885, fasc. 3918 «42/6. Malaria. Complessiva», 1886-1891.

$\left({ }^{11}\right)$ ACS, MAIC, DGA, Versamento II, b.198, fasc. 1422 «32. Meteorologia. Complessiva. Dal 1873 al 1878», 1873-1878.

$\left.{ }^{12}\right)$ «Per ben venti stazioni, ripartite sulla faccia della penisola, si espongono in forma comparativa, le vicende decadiche dei principali elementi meteorici, tantochè, quasi a colpo d'occhio, può argomentarsi l'andamento generale delle grandi perturbazioni e delle variazioni diurne occorse in tutte le parti d'Italia, e lo si può di poi facilmente paragonare a quello contemporaneamente verificatosi nelle altre regioni d'Europa».

$\left({ }^{13}\right)$ «[...] di dare unità e vita ai servizi meteorici che fra noi giacciono sperperati e malfermi sotto vari ministeri, creando un istituto meteorico centrale, sul tipo di quelli dell'Olanda, della Danimarca e della Svezia, il quale valga a ridurre ordinate e feconde le tante osservazioni che si van facendo nelle numerosissime stazioni meteoriche, marittime, idrometriche, che sono nel Regno nostro».

$\left({ }^{14}\right)$ Royal decree 9th June 1887, n. 4636.

$\left({ }^{15}\right)$ ACS, MAIC, DGA, Versamento V, b. 965, fasc. 4242 «90/1. Osservatori geodinamici. Roma. Osservatorio e Archivio Centrale Geodinamico», 1881-1892.

$\left({ }^{16}\right)$ «Parmi innanzi tutto dover ricordare ciò che è ben noto a codesto Ministero, essere ciò̀ io stato senza mia richiesta direttamente invitato nel 1882 da s.e. il ministro a recare presso il Regio Comitato Geologico l'archivio geodinamico da me formato, per continuarlo e farne il centro di un servizio geodinamico, unitamente alla ben nota pubblicazione del Bollettino del Vulcanismo Italiano. [...]. Ricordo inoltre come la Regia Commissione Geodinamica poscia nominata, per proporre l'assetto definitivo del nuovo servizio scientifico, riconoscesse la proprietà personale di detto archivio con l'annesso nucleo di biblioteca geodinamica, proponendo a codesto Ministero l'acquisto di esso per la parte anteriore al 1883; dal quale anno cominciava poi la raccolta delle notizie e documenti fatta per mezzo del piccolo ufficio allora fondato dal Ministero sotto la direzione dello scrivente».

$\left({ }^{17}\right)$ «[...] anche quelli la cui conoscenza, per la loro tenue gravità, non esce dai confini della città o abitazione nella quale sono avvenuti».

$\left({ }^{18}\right)$ ACS, MAIC, DGA, Versamento V, b. 962, fasc. 4230 «90. Vulcanologia. Affari generali. Disposizioni generali», 1883-1888.

$\left({ }^{19}\right)$ «Fra i bisogni del servizio geodinamico vi è quello degli osservatori volanti, oltre quello degli osservatori stabili. Chiamiamo "osservatori volanti" un corredo di istrumenti portatili, i quali servono non solo nelle escursioni ed esplorazioni, ma anche per organizzare piccoli osservatori temporanei dove se ne manifesti il bisogno, in seguito alla comparsa di un periodo sismico o d'altro genere di manifestazione endodinamica. Anche a questo bisogno, malgrado la mancanza di mezzi, si è provveduto con qualche istrumento; e nel corrente anno funzionano di tali osservatori temporanei in Cascia in Palazzuolo, presso Albano, in Serrara Fontana e in Ischia. Parlando dell'operato del servizio geodinamico, devesi accennare all'istituzione di una rete di stazioni fornite di qualche sismografo, distribuita nelle falde dell'Etna, con un osservatorio regionale centrale in Catania, mercé le cure del direttore dell'Ufficio meteorologico comm. Tacchini. Anzi il medesimo, per quanto lo scopo del suo servizio meteorologico lo comportava, ha procurato anche fornire, ad alcuni più meritevoli fra gli osservatori meteorologici, un qualche avvisatore sismoscopico per lo studio dei terremoti di una certa intensità». $\left({ }^{20}\right)$ ACS, MAIC, DGA, Versamento V, b. 967, fasc. 4249 «90/1. Casamicciola. Osservatorio Geodinamico», 1884-1891. 
$\left({ }^{21}\right)$ «[...] per far conoscere come debbano essere definiti e intesi alcuni concetti essenziali nella discussione». ${ }^{(2)}$ «Lo studio dell'attività interna della terra, che chiamiamo Geodinamica, è ora organizzato nella forma di osservazioni continue e con appositi istrumenti, perchè si è visto essere questo il solo metodo per indagarne le leggi e scoprirne le cause. La previsione dei fenomeni pericolosi non è lo scopo diretto di questo studio ma potrà discenderne come risultato. Interessa perciò principalmente l'organizzare tali osservazioni nei luoghi ove esistono le maggiori manifestazioni dell'attività interna».

$\left({ }^{23}\right)$ «Il metodo sperimentale delle osservazioni scientificamente regolari fatte in appositi osservatori ha dimostrato vera l'esistenza finora empiricamente conosciuta di fenomeni precursori. Conosciuto che sia in avvenire l'andamento di detti fenomeni, diverrà possibile anche una scientifica previsione dei fenomeni maggiori».

$\left({ }^{24}\right)$ «Non si deve credere che debba avere l'ufficio di informare giornalmente il pubblico dello stato dinamico della terra, ma poiché in esso si dovrà tenere conto esatto di tutti i fenomeni diversi notati nell'isola intera, allorché si verifichi il complesso di uno straordinario cumulo di tali fenomeni, quale sembra essere avvenuto prima del 28 luglio, si avrà ragione di sospettare e anche di avvertire la probabilità di un fenomeno parimenti straordinario».

$\left({ }^{25}\right)$ ACS, MAIC, DGA, Versamento V, b. 963, fasc. 4233 «90. Commissione Reale per il riordinamento del servizio geodinamico», 1883-1887.

$\left.{ }^{(26}\right)$ «La Commissione è partita dal concetto che nelle attuali circostanze non sarebbe né utile né opportuno di consigliare al governo l'impianto di un vero e proprio ufficio centrale geodinamico. [...] Il servizio di meteorologia e quello di geodimamica hanno tra loro grandi analogie: si occupano entrambi di un ramo della fisica terrestre ed entrambi si esplicano per via di osservazione. Trovandosi quindi impiantata un'estesa rete di osservatori per le osservazioni meteoriche, evidente si chiariva la convenienza di trarre profitto da essi per stabilirvi anche le osservazioni sismiche. Si poteva in tal modo non solamente realizzare una rilevante economia, ma dare agli studi e alle osservazioni un indirizzo unico. Fu perciò pensato di sottoporre $i$ due servizi a un'unica alta direzione e riunirli sotto un solo ufficio centrale. [...] Mercé la grande attività e l'autorità del Tacchini, il servizio geodinamico acquisterà il grande sviluppo che tutti riconoscono alla meteorologia italiana». $\left({ }^{27}\right)$ «Purtroppo bisogna confessare che siamo stati scavalcati da altri paesi e che, continuando con l'andazzo finora seguito, l'Italia non sarebbe mai stata nel caso di fare degli studi strettamente scientifici sui movimenti del suolo».

$\left({ }^{28}\right)$ ACS, MAIC, DGA, Versamento V, b. 963, fasc. 4234 «90. Vulcanologia. Affari generali. Pubblicazioni estranee. Lavori scientifici inviati al Ministero e proposte di acquisto», 1883-1889.

$\left({ }^{29}\right)$ «La commissione esprime parere che l'avvenire degli studi sismici in Italia sia fondato sulla possibilità d'impiegare strumenti registratori i quali siano atti a segnare le tre componenti dei moti del suolo, in modo possibilmente indipendente dai moti propri dello strumento e colla maggior possibile sensibilità. Sotto questo punto di vista essa raccomanda ai direttori degli osservatori principali di fornirsi al più presto possibile degli strumenti proposti nella relazione Grablowitz e di sottoporli a un esame pratico, onde constatare quali di questi corrispondano meglio allo scopo sopracitato».

$\left(^{30}\right)$ ACS, MAIC, DGA, Versamento V, b. 967, fasc. 4249 «90/1. Casamicciola. Osservatorio Geodinamico», 1884-1891.

\section{REFERENCES}

Caracciolo, A. (1960): Stato e società civile. Problemi dell'unificazione italiana (Einaudi, Torino), pp. 34-53.

DE CESARE, C. (1868): L'amministrazione dell'agricoltura, dell'industria e del commercio durante l'anno 1868 (G. Pellas, Firenze)

ERAmo, N. (1995): Fonti per la storia della scienza e della tecnica negli archivi del MAIC, in Gli archivi per la storia della scienza e della tecnica, International Meeting, Desenzano del Garda, Italy, 4-8 giugno 1991 (Ministero per i Beni Culturali e Ambientali - Ufficio Centrale per i Beni Archivistici, Rome), pp. 1019-1039.

ERAMo, N. (1996): Fonti per la storia delle acque di Roma e del Lazio, Rivista storica del Lazio, 4, 163-193. 